\title{
Obstacles to the Adoption of Self-Service Technology at Cairo International Airport
}

\author{
Ghada Mohamed Khairat \\ Faculty of Tourism and Hotels \\ University of Sadat City
}

\begin{abstract}
Due to the advancement and proliferation of information and communication technologies in today's world, self-service technology (SST) applications have become increasingly prevalent. SST is a technology that enables users to produce a service independent of direct service employee involvement. As more and more airlines have introduced technology-based self-check-in services, it has become increasingly important to understand the factors affecting airline passengers' attitudes and intentions toward this new form of check-in services. Therefore, this study aims at investigating passengers' intention toward using check-in kiosks and exploring the obstacles to applying self-service check-in kiosks at Cairo International Airport. The field study is based on in-depth interviews with 20 Executive directors of Cairo International Airport, Station directors, employees of Egypt Air, and 30 passengers at Cairo International Airport. The results indicate that passengers are not commonly using Self-service check-in kiosks and had rejected the kiosks due to some obstacles. Finally, this study suggests that airlines should persuade passengers to acquire a more positive attitude toward the new check-in kiosks. Airlines also should implement incentive strategies to encourage passengers adopting the self-check-in service.
\end{abstract}

Keywords: Self-service technology; Airline check-in kiosk; Technology readiness.

\section{Introduction}

Rising labor costs have encouraged companies to explore more self-service options that allow customers to perform services by themselves. Moreover, innovations in technology have contributed to the growth of technology-based self-services, allowing companies to use a variety of self-service technologies (SSTs) that increase customer participation. ${ }^{1}$ Self-service technology (SST) is defined as technological interfaces that aid users in generating service without direct involvement from the service company's employee. ${ }^{2}$ SST has become more and more widespread and replaced traditional face-to-face services. ${ }^{3}$ It has changed how existing companies do business and enabled the creation of new types of business ${ }^{4}$ SSTs have dramatically changed the way in which firms interact with customers, ${ }^{5}$ giving the customer the duty to carry out the service with the use of technology either through internet or visual aids. This type of technology is moving the responsibility to the customer ${ }^{6}$ The replacement of human service by a technology usually requires both the development of new knowledge and behavior associated with the service and increased customer responsibility in the production of the service ${ }^{7}$ Many service providers have begun to use a wide range of technologies in the process of service delivery, allowing customers to enjoy services electronically without direct contact with service employees ${ }^{8}$

The benefits of SST adoption include labor cost reduction, enhancing efficiency, ${ }^{1,5}$ improving productivity and service quality ${ }^{9}$ It also increases corporate performance, improves service operations, ${ }^{8}$ improves competitiveness and increases market share, increases customer satisfaction and customer loyalty, and differentiates through a technological reputation .${ }^{10,11}$ From the customers' perspective, SSTs enable them to enjoy the services they require with a more flexible choice of time and space, and through more channels.$^{8}$ Although self-service technology can bring the benefits of convenience, perceived control, and flexibility to customers, in the rush to implement SST, firms often disregard technology failures and the associated risk of losing customers because of technology related difficulties.$^{12}$ However, technological problems such as technology failures, process failures, service design problems, technology design problems, and customer driven failures may inhibit the adoption of self-service technology. The challenge facing self-service technology is about getting customers to use the technology ${ }^{13}$ So, adopting SST does not necessarily result in a positive outcome, ${ }^{14}$ and does not automatically lead to its usage. Many technological innovations are radical or really new to customers, and cause apprehension in those who lack sufficient experience with the technology.$^{15}$ Customers may avoid it if they are not comfortable with and/or ready to use the technology. Moreover, customers' adoption of technology will vary according to the characteristics of the individuals. When customers face technology, different psychological reactions occur, depending on the individuals' feelings toward the technology-based system ${ }^{8}$ 
The key determinants of SST intention can be generally classified into two broad categories: SST characteristics and individual differences. So far, the main SST characteristics include usefulness, ease of use, enjoyment, risk, and control. In terms of individual differences, they can be further categorized into demographics and psychographics. Primary demographics that have been found to influence SST usage intention are age, gender, education, and income; whereas main customer psychographics include technology anxiety, technology readiness, and need for human interaction.$^{16,3,17}$ Air traffic is growing continuously, but the development of airports is constrained by the funding and space available to expand the terminal. Therefore, airports have to develop the terminal facilities and meet new standards of operational efficiency. Airports have started implementing new technologies at the terminals for convenience of the passengers. The new solutions strive to improve operational efficiency and reduce queues at the airport.$^{18}$ Airport infrastructure is the first and the last point of contact at a destination. The new technology like self-service kiosks are designed as one form of airport infrastructure and act as a time saver for passengers, cost saver for airlines, and space saver for airports. Most major airlines have already invested in installing self-service kiosks to save expense at the check-in, offer a better service to their passengers, and build an image of maintaining a leading position in electronic service ${ }^{\mathbf{1 9 , 2 0}}$ Now airlines and airports are using new procedures to deliver faster and smoother services to airline passengers.$^{21}$ The aim of this study is to investigate passengers' intention toward using SST for airline check-in kiosks, and explore the obstacles to use self-service check-in kiosks at Cairo International Airport.

\section{Literature Review}

Self-service technology (SST) is technology interface that enables customers to produce and use a service independent of direct service employee involvement; ${ }^{22,23,24}$ and it allows customers to interact with self-service software. ${ }^{25}$ Examples of SST in use are ATM, Pay at the pump, Internet banking, Airport self-check-in, Automated hotel check-in/out, Automated car rental, gambling machines, distance learning/training, Internet information search, Internet shopping, Automated driver's license testing, various vending services, food ordering kiosks and various interactive voice response phone systems. $^{26,27}$

\section{Types of SSTs}

There is a classification which has divided SSTs into four dimensions: ${ }^{12,28}$

1) Telephone \& Interactive Voice Response (IVR) systems which allow consumers to interact with a computer system through speech recognition technology. Companies can provide information over the telephone using text-to-speech technology. Furthermore, many companies utilize this form of SST for customer orders, customer billing inquiries, and customer surveys.

2) Interactive free-standing kiosks which provide users access to information or a service, such as checking an account balance at an ATM or checking in for a flight at an airport kiosk. Many malls and retail outlets offer such services both inside and outside their stores. This helps customers determine availability of a product, as well as locate it in their facility. There are also print coupons kiosks at airports and hotels which allow printed airline tickets and quick checkout. Today's technology makes kiosks more affordable and convenient. Kiosks are often equipped with advanced technology like touch screen displays, card readers, scanners, thermal printing, Power over Ethernet ( $\mathrm{PoE}+)$ and wireless networks. The availability of broadband Internet access has made deploying consumer-friendly computer kiosks a cost-effective option for many services . ${ }^{\mathbf{2 9 , 3 0}}$

3) Internet based and other direct online connection systems.

4) Video/DVD/CD based technologies: This type of SST is typically used for educational purposes. Corporate entities use this media to train their employees, to familiarize sales representatives with new products, and to introduce new products to customers. Universities have also gotten into the act in the last decade, providing undergraduate, graduate, and continuing education classes by video and CD formats.$^{31}$

Additionally, according to ${ }^{32,22}$, SST is divided into two groups: Internet and non-Internet SSTs. Examples of Internetbased SSTs are online banking, online tax-file number registration, online hotel or airline reservation and transaction. More advanced tools continue to be introduced by firms as a response to the competitive business environment and the availability of more innovative technology. Examples of Non-Internet SSTs are ATMs or vending machines, self-cash registers in grocery stores, information kiosks at malls, automated hotel checkout processes, automated self-check-in machines in the airports, and self-scanning machines in the library are very common. On the other hand, ${ }^{33}$ SST is segmented into three application areas: online (e-commerce), kiosk (k-commerce), and vending (v-commerce). 


\section{Business Goals for SST}

Companies typically seek to fulfill at least one of three primary business goals when they choose to enter the self-service arena ${ }^{12,34,35,36}$

1) Customer service (technology delivered customer service): The intent here is to provide the customer service without tying up the company's human resources. Questions regarding accounts, bill paying, frequently asked questions, and delivery tracking are just a few examples of customer service that are now provided through SSTs.

2) Direct transactions: The technology enables customers to contact with companies to order, buy and exchange resources without any direct interaction with the companies' employees.

3) Educational (Self-Help): which refers to technologies that enable customers to learn, receive information, train themselves, and provide their own services.$^{37}$

\section{Factors Affecting SST Adoption and Use}

The successful implementation of SSTs is dependent on wide customer adoption in order to justify the investment cost. ${ }^{7}$ Therefore, the need to understand customer decisions regarding SSTs has drawn scholars' attention into the factors facilitating customer adoption.$^{38}$ It is important to understand the factors that determine both willingness and resistance of the customers on using the SSTs ${ }^{39}$ many factors influence the adoption or rejection of technology-enabled services. These factors include: innovation attributes and customer characteristics, ${ }^{\mathbf{1 2 , 4 0 , 4 1}}$ see figure 1.

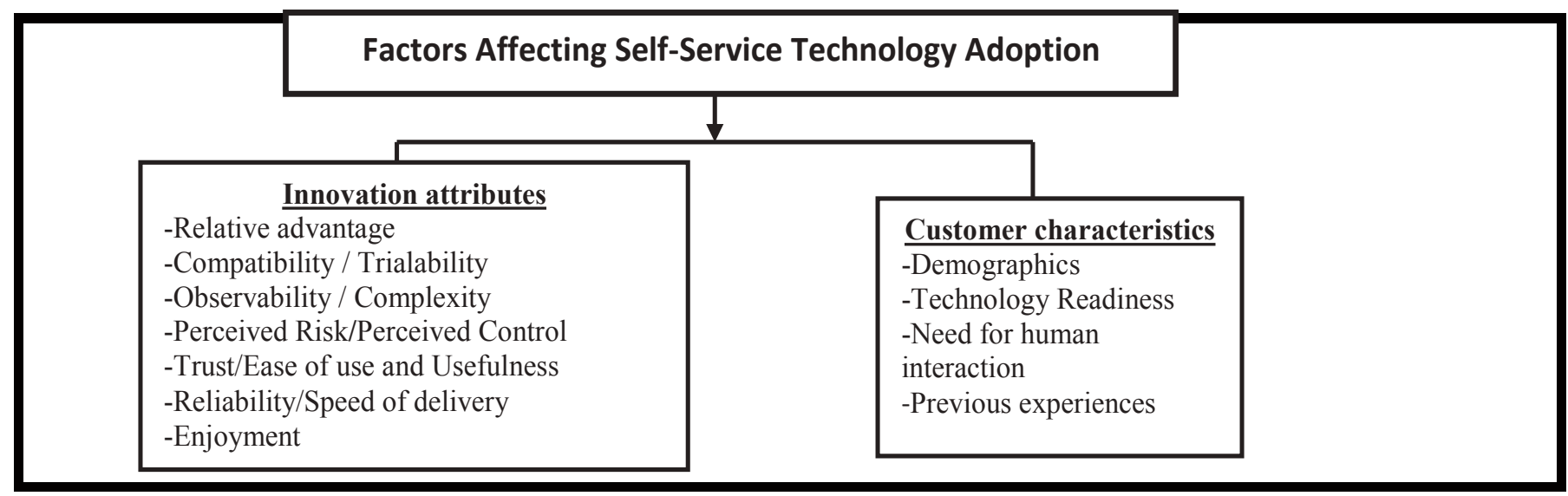

Figure (1): Factors affecting Self-Service technology adoption

\section{Self-Service Technology Characteristics:}

The adoption rate of an innovation is determined by the customers' perceptions of the innovation characteristics. five innovation attributes are considered to be important: relative advantage, compatibility, trialability, observability, and complexity. ${ }^{3}$ In addition, a large number of studies have also investigated other innovation attributes such as, perceived risk. ${ }^{32}$ perceived control, ${ }^{42}$ trust, ${ }^{9}$ perceived ease and perceived usefulness, ${ }^{38}$ reliability, speed of delivery, and enjoyment . ${ }^{41,43,44}$

- Relative advantage is defined as "the degree to which an innovation is perceived as being better than the idea it supersedes", whereby the relevance of the advantage depends on the nature of the innovation, and the extent to which services are perceived or believed to offer relative benefits advantages over more traditional face-to-face encounters..$^{40,42}$

- Compatibility is the degree to which an innovation is perceived with the need and existing values of potential adopters. The adoption rate is suggested to increase when the innovation is compatible with the adopter's needs, socio-cultural values and beliefs and previously introduced ideas. ${ }^{41}$

- Trialability is the degree to which an innovation may be experimented with on a limited basis; it is important, since in case the innovation is easy to use for the first time without substantial consequences, the customer has the possibility to gather information about the innovation and attach a meaning to it, which in turn reduces the uncertainty associated with the innovation..$^{45}$

- Observability is the degree to which others can observe the result of innovation and an indication of the chance to see others use the SST. ${ }^{46}$ 
- Complexity is the degree of perceived difficulty in understanding and using the innovation. Any new idea may be classified on the complexity-simplicity continuum, but it is also a perceived attribute to potential adopters.$^{41}$ Moreover, two dimensions were suggested to analyze services: First, service complexity, defined as the number and intricacy of steps required to perform the service. Second, service divergence, which is the degree of freedom allowed in or inherent to a particular sequence of the process. ${ }^{47}$

- Perceived risk (PR) is the extent to which technology-enabled services are perceived to be sufficiently safe, secure and reliable to use.$^{40}(\mathrm{PR})$ is commonly thought of as feeling uncertainty regarding possible negative consequences of using a product or service, such as system failure and other risks associated with using the service. This is associated with a number of ideas such as, performance risk, financial risk, social risk, time risk, ${ }^{32,48}$ and psychological risk . ${ }^{49}$

- Perceived control: Locus of control is described as a belief individuals hold that failures or successes of the usage of SST are mainly resulted from their own actions or due to external uncontrollable factors. ${ }^{2}$ Previous studies posit that individuals' locus of control is related to motivation, beliefs, adoption, emotions, satisfaction, and behavioral intentions of innovative ideas. Moreover, it refers to a customer's sense of independency and of mastery over the processes and outcomes of the service interface. It is also a specific situation (psychological outcome) that is often influenced by environmental conditions and customer traits, such as self-efficacy in handling a specific technology $50,51,52,53$

- Trust: The infusion of technologies in service encounters may not be welcomed by customers, regardless of the obvious benefits. Furthermore, two main concerns to the adoption of SSTs by customers have been proposed: the preferences of some customers for interpersonal encounters during service, and the issue of privacy and confidentiality. ${ }^{54}$ Exchange theories posit that trust is a catalyst in customer marketer relationships because it provides expectations of competent, reliable performance and successful transactions. Trust includes three subdimensions: ability, benevolence, and integrity. High levels of customer trust in technology encourage satisfaction with SSTs and purchase intentions. ${ }^{9,32}$

- Perceived Ease and Perceived Usefulness: Perceived ease of use is defined as 'the degree to which a person believes that using a particular system would be free of effort ${ }^{55}$ In addition, ${ }^{43,56}$ concluded that ease of use is essential to customers' acceptance of the SST, and there is a link between technology discomfort and perceived ease of use. Self-service systems must be easy to use in order to achieve a higher adoption rate.57 on the other hand, usefulness is the subjective probability that using the technology would improve the way a user could complete a given task .38 Perceived usefulness is defined as 'the degree to which individual believe that using a particular system would enhance their job performance' ${ }^{32}$

- Reliability refers to the accurate functioning of an SST and the corresponding service, which positively impacts the attitude toward using SSTs ${ }^{58}$ If a service is unreliable, apologies and a friendly staff cannot compensate for it.$^{12}$

- Speed of Delivery: Expected speed of delivery is defined as the customer's expectation of the time it would take to actively perform the service. Customers today are highly sensitive to the speed of the service delivery; they usually overestimate the time taken to deliver a service. Some people prefer to perform the service themselves specifically to reduce delivery time.43,59. 60 found that time was very important to those who preferred self-service. Therefore, slow service delivery affects the overall perceptions of service quality. Thus, if customers expect that a service will be delivered speedily, they are likely to evaluate the service more highly.$^{43,61}$

- Enjoyment refers to being enjoyed when someone uses technology-based self-services options . (0,62 $^{\mathbf{2}}$

\section{Customer Related Factors:}

The second main approach influencing the adoption of SSTs focuses on customer traits which include demographics, customer psychographics, and personality traits.

\section{Demographics}

Age, gender, education and income are of the most demographic researched variables in relation to SSTs since they offer good base for traditional marketing segmentation. Demographics have been examined as direct antecedents of usage, since they are influencing beliefs and attitudes or personality traits.$^{32,63}$ In a study by ${ }^{64}$, customer's age was shown to have little influence on adoption of self-scanning. In contrast, a study specifically of the age variable by ${ }^{65}$ found that there are differences in the adoption of SSTs between the different age groups. He divided his sample into three age groups: 18-28; 29-48 and 49+. The study concluded that as the segmentation is getting older, a negative effect has been reflected on three 
variables: preferences for SST to human contact, confidence to use SSTs, and belief in the benefit from using technology. SST users are younger on average than non-users. ${ }^{65,66}$ Younger customers have a high chance for purchasing and using new customer electronic products.$^{67}$ Aging has a complex effect on cognitive abilities. Age is also associated with a decline in morphological and functional structures, which are key resources for perceptual skills, working memory, processing speed, and the encoding of information into episodic memory. Moreover, verbal and computing skills reach their optimal level between the ages of 30 and 50 years and decline very slowly after 50 years of age ${ }^{47}$ People differ in their sensitivity to time-related issues depending on their educational background. People who have more highly qualified jobs and education levels tend to display more quantitative time orientation. This has led them to attach more importance to the time gain that comes with using SSTs. Newness of SSTs in itself may have some utility for customers. Higher education has generally been found to be positively associated to a higher probability of using new technologies ${ }^{\mathbf{6 6}}$

The interaction between demographics (e.g. age, gender, education and income) and personality traits (e.g. technology anxiety, need for interaction and technology innovativeness) and their effect on intentions to use SSTs was researched by. ${ }^{63}$ Their findings show that customer demographics influenced SST usage intentions through the mediating effect of personality traits. For example, men exhibited a greater level of technology innovativeness and less technology anxiety; older people needed more personal contact, showed more technology anxiety and less technology innovativeness; while customers with higher income were less anxious about technology. ${ }^{63}$

- Technology Readiness (TR) has been suggested as a factor that fosters or hinders the acceptance or rejection of new technology . ${ }^{22}$ TR is defined as "people's propensity to embrace and use new technologies for accomplishing goals in home life and at work" . ${ }^{68}$ New technology can generate both positive and negative feelings ${ }^{32,8}$; feelings of enjoyment ${ }^{32}$ or anxiety ${ }^{56}$ which directly or indirectly affect customers' attitude, beliefs, and behavior toward technology. ${ }^{15,69}$ Furthermore, eight paradoxical emotions that customer has to cope with regarding new technology have been identified as follows: control/chaos, freedom/enslavement, new/obsolete, competence/incompetence, efficiency/inefficiency, fulfilling/creating needs, assimilation/isolation, and engaging/disengaging. ${ }^{70}$

Technology readiness is based on four dimensions, two factors being motivators of new another two being inhibitors as follows : $:^{71,72,73}$

technology use and

(1) Optimism: A positive view of technology (belief in increased control, flexibility, and efficiency in life due to technology).

(2) Innovativeness: A tendency to be the first using a new technology (a tendency to be a technology pioneer and thought leader).

(3) Insecurity: Distrusting of technology and skepticism about its ability to work properly.

(4) Discomfort: A perception of lack of control over technology and a feeling of being overwhelmed by it.

- Need for human interaction is defined as a desire to retain personal contact with others during a service encounter. Historically, service encounters have involved interpersonal interactions between customers and service providers. These interactions allow for the development of interpersonal relationships between a customer and service provider. However, using SSTs, by definition, eliminates this interpersonal interaction ${ }^{38}$ The use of technologyenabled services would be influenced by the extent to which personal contact is perceived as needed or preferred. On the one hand, some people prefer technology-enabled service provision precisely because it eliminates the need for personal contact (interaction with service personnel and other customers) in addition they find it enjoyable.$^{10,58}$ On the other hand, others prefer to deal or interact with people rather than machines, which are often thought to be impersonal and incapable of providing personalized service.$^{43,58}$ Therefore, it is reasonable that customers who desire personal interaction in the service encounter may be reluctant to adopt and use technologically facilitated means of service provision $.40,74$

- Previous experiences with technology-based products and services have been shown to consistently play a role regarding SST adoption. Past negative experiences with automated systems and technological products are reasons for not wanting to use self check-in options of airlines. The lack of computer experiences seems to inhibit customers to adopt self-service technology.$^{3}$ Also, past experiences influence SST attitudes and behavior in a more complex manner. . $^{17,75}$

\section{Strategies for the Success of SST Kiosks}

The key factors for the success of SST kiosks are ${ }^{14}$ as follows: 
The interface design: It is one of the important factors in the use of kiosks. A well-designed interface should be evaluated in terms of the functional features from the users' perspective. The functional features will determine the efficient and effective work to complete the information search or transaction on the kiosks. An interface design with a simple but useful layout helps customers stay focused on what they want. Interface design of the kiosks also should meet customers' needs and wants which change over time. Interface design matters greatly to customers, affecting their perceptions of technologies and service encounters ${ }^{44,51,76}$ Therefore, updating kiosks with an improved interface design is one of the important concerns to service providers.$^{12}$

Accessibility: Accessible kiosks are mainly determined by their location. A good location increases visibility and therefore, the number of users.

Employee Readiness: Successful kiosks are designed with many human factors in mind. Although kiosks are designed to off services created by customers, employee assistance is still an integral part for kiosk success. Well trained employees encourage customers to use kiosks and help customers whenever they have problems while using kiosks. In this way, more customers appreciate kiosks and the company can effectively prevent service failures caused by difficulties with the system.

Promotion: The company aggressively announces the availability of SST kiosks to their customers to encourage kiosk use. The kiosks are featured in their advertisements, catalogs, and throughout the stores ${ }^{12}$

Fulfillment: Fulfillment is referred to as one of the most expensive and critical operations, but also as one of the most integral parts in improving customer service in multi-channel shopping. Accurate and timely delivery with no failures can be a competitive advantage to a company.

Communication strategies: Companies also focus on educating the customers on how to use new technology, minimizing unpredictable aspects of the technology, and assuring the benefits related with using the technology.$^{22}$

Advantages and Challenges of SSTs

Self-service technology provides advantages for service providers and customers alike. The main benefits to service providers from successfully implementing SSTs are: operational cost reduction, increasing customer satisfaction and loyalty, ${ }^{32,40}$ reaching of new markets, allow staff to be relieved from routine duties, labor reduction, more consistent service delivery, expanded service delivery, and increased operational efficiency. ${ }^{44,77}$ From the customers' perspective, SSTs provide greater flexibility to choose service delivery method, greater control over service delivery, ease of use, enjoyment with SST interaction, faster response, communication in native language, avoidance of service personnel, more privacy, and added convenience. They also save money and time. ${ }^{78,79}$

However, ${ }^{23}$ have found key drivers of customer dissatisfaction with SSTs as follows:

- Technology failure: Contrary to "did its job", failure occurred when the technology did not work as intended. This failure is a malfunction of delivery when the customer is interacting with the technology. Examples for this failure are broken machines, websites down, inability to log on the system, and failing to use personal ID.

- Process failure: it is the Failure in the process after the customer technology interaction. For example, an on-line banking customer might pay his/her bill on-line, however, process failure results in the customer not being credited with payment. This process failure causes substantial dissatisfaction since customers do not know about the failures until notified that they have not done something which they have actually done.

- Poor design: "Technology Design Problem" and "Service Design Problem" are two components of "Poor Design". Although the SST may function as designed, it performs in such a way that customers are dissatisfied with the service encounter; for example, an SST that is difficult to use or understand.

- Customer-driven failure: Some customers accept that the failure sometimes occurs because of their own actions. For example, ATM users may realize that entering the password incorrectly might have contributed to dissatisfaction with the service encounter.

- Cultural factors: Cultural constructs greatly impact a customers' attitude towards utilizing SST ${ }^{80}$ Culture is strong evidence that shared beliefs, expectations, values, attitudes and behaviors influence the use of communication and information technology. Culture beliefs are likely to have a significant effect on the use and acceptance of selfservice technology .22,81

- The customer messes up: For example, the customers might lose their pin number or password, or fail to provide requested information. ${ }^{80}$ 
- Lack of human interactions and elimination of social experience: Even people who have favorable attitudes toward technology may avoid SSTs because they cannot replace the personal interaction.$^{14,81}$

- Uncomfortable feelings toward technology (Technology discomfort): It is the tendency of an individual to feel uneasy, apprehensive, stressed or to have anxious feelings about the use of SSTs.$^{56}$

Moreover, the limitations of SSTs from a service provider perspective are related to investment expenses, and staff and customer training. Furthermore, companies struggle to persuade their customers to adopt new self-service technologies. If the service technology does not gain adoption with customers, the company may face increased expenses because it needs to keep the operational staff, as well as pay for the new technology. SSTs also reduce the points of customer contact during the service delivery process which leaves fewer chances for early detection of complaints and opportunities for service recovery. ${ }^{15,32}$

\section{Self-Service at the Airports}

In recent years the airlines have started using innovative check-in technologies. Self-service check-in kiosks are now an integral part of the airport facility. This process enables airlines to reduce the time and number of staff required, thus, saving substantial costs in operation. In addition, it reduces queuing time, increases productivity and enhances operational efficiency.$^{\mathbf{2 5 , 8 2}}$ The customer has a range of options to commence the check-in process. First, the passenger can scan his frequent flyer card, his passport or credit card in order to open his passenger file. Then, the kiosks will complete the checkin process, issuing a boarding card. The airlines vary with their respective kiosks' functional ability to issue baggage tags ${ }^{\mathbf{8 2}}$ Airlines have invested heavily in airport kiosks to allow customers to manage their reservations. Airport kiosks with touch screen displays, magnetic stripe card readers, and bar code scanners are now common in airports around the world. These kiosks allow customers to check-in for their flights, change or upgrade their seats, modify their reservation, and even purchase a ticket. Moreover, travelers without baggage can check-in and then proceed directly to the gate; and travelers with baggage can check in and then take their luggage to the baggage drop.$^{29}$

As the airline industry continues to grow and the demand for SST changes, airlines have taken hold of SST and have been able to provide customers with the technology they have longed to use. Airlines are now putting the power in the customers' hands and allow them to perform multiple tasks that once could only be completed by a service employee.$^{83}$ Furthermore, SST provides customers with various benefits that would not be possible if the customer used a service employee. These benefits include: increased control over the service delivery; as the customer is in control of the process, convenience; as SST is available at almost every hour and at multiple locations, reduction in customer wait times; as lines tend to be shorter, and flexibility in use; as many tasks can be completed in a central location for multiple airlines . ${ }^{84}$

Airport SST consists of many sub-systems that help passengers take the necessary action by themselves. The systems currently adopted in many airports according to ${ }^{85}$ include:

- Information kiosk, which is a standalone terminal that provides information, goods and services ${ }^{86}$

- Ticketing kiosk, which is a place where passengers can review prices, purchase airline tickets, confirm reservations, check baggage and monitor flight times and status.. A self-service kiosk is able to confirm a traveler's identity by prompting him or her to input a confirmation number and insert the credit card used to purchase tickets. $^{33}$

- Common Use Self Service (CUSS) kiosk, which is a shared terminal with multiple airlines that helps ease congestion and reduce long lines at check-in counters.

- Retail kiosk, where customers can purchase food, magazines, or souvenirs and goods before or after a flight . ${ }^{14}$

International Air Transport Association (IATA) has announced a five-pronged strategy constituting the 'Simplifying the Business' initiative. This initiative launched in the year 2004, and it includes: ${ }^{19,87}$

- $\quad$ BCBP - Bar Coded Boarding Pass - assigned for electronic boarding passes.

- $\quad$ IATA e-freight - managing cargo freight through electronic messages, reducing paper work.

- CUSS - Common Use of Self-Service -Self service kiosks provided for easy passenger check-in without help of ground staff.

- $\quad$ BIP - Baggage Improvement Program - aimed at hassle free baggage transportation.

- $\quad$ Fast Travel Program - travel made easier by providing more self-service options for passengers. 


\section{Cairo International Airport and Common Use Self-Service (CUSS) Kiosks}

Common Use Self-Service (CUSS) is a shared kiosk offering check-in facilities to passengers without the need for ground staff. The CUSS can be used by several participating airlines in a single terminal ${ }^{\mathbf{8}}{ }^{\mathbf{T}}$ This evolving pattern enables passengers to obtain boarding passes, check baggage, and conduct other transactions at times and places of their convenience. Passenger check in procedures will gradually shift from check-in procedures performed at check-in counters to check-in procedures performed through self-service check-in facilities at the airport, such as CUSS. The trend is toward common use equipment which may consist of free standing column type or counter type workstations with built-in Automated Ticket and boarding pass printer. The CUSS is used by self-service passengers to check-in, seat allocation, boarding pass printing and baggage check-in in a common use environment ${ }^{25}$ Figure.2 represents A CUSS Kiosk Machine.

The CUSS concept is a kiosk platform to be shared by any number of CUSS standard conformed

check-in applications. It was developed by a mix of airlines, airports and suppliers.$^{30}$ Self-service check-in kiosks have become the common check-in mechanism and a permanent fixture in Europe, US and in many airport terminals. CUSS was designed to enable airlines to provide a range of passenger facilities at a shared kiosk. In 2003, CUSS kiosks began to be deployed across airports worldwide in significant numbers ${ }^{89,}{ }^{90}$ In the Middle East region, it started as a dedicated selfservice, and the first CUSS kiosk have been installed at Cairo International Airport terminal building 3 (TB3) by the airport's systems supplier - ARINC incorporated and Société Internationale de Télécommunications Aéronautiques (SITA), the world's leading service provider of integrated IT business solutions and communication services for the air transport industry. ${ }^{25,91}$ Figure. 3 shows the penetration of CUSS across airports worldwide.

In 2006, ARINC Managed Services was contracted to provide advanced passenger check-in systems and IT technologies for TB3 at Cairo International Airport. These IT systems included: Common Use Terminal Equipment (CUTE), Common Use Self-Service (CUSS), IMUSE Common-Use Passenger Check-In and Departure System, IP-enabled AirVUE Flight Information Display System (FIDS), AirDB Airport Operational Database (AODB), Local Departure Control System (LDCS), Biometric Systems (BS), Ramp Management System, Local Area Network ( LAN), Information Kiosk System, Airport Recourse Management System, Network Management System, Voice over IP (VoIP), Information Broker System (IBS), and Baggage Reconciliation System (BRS).$^{91,92,93}$

The kiosk systems currently employed at most primary airports can be divided into two groups: CUSS kiosks, which comply with the IATA CUSS specifications and are shared by a number of airlines, and dedicated kiosks installed by individual airlines . ${ }^{19,82}$

The creation of the CUSS was to provide efficiency and profitability for all subscribing airlines. From the financial perspective the CUSS offers subscribing airlines a reduction in cost per passenger, reduced check-in processing time, physical infrastructure (reduction in queuing space and counter space) and length of time of kiosk return on investment. The CUSS kiosk has become convenient and desirable for both the airlines and passengers that utilize such devices, as its use can be beneficial to all. ${ }^{82,94}$ Furthermore, the main aspects to be considered in the placement of kiosks are ${ }^{18}$ :

- Visibility.

- Accessibility and movement of passenger traffic.

- Comfort and privacy of the passenger. 


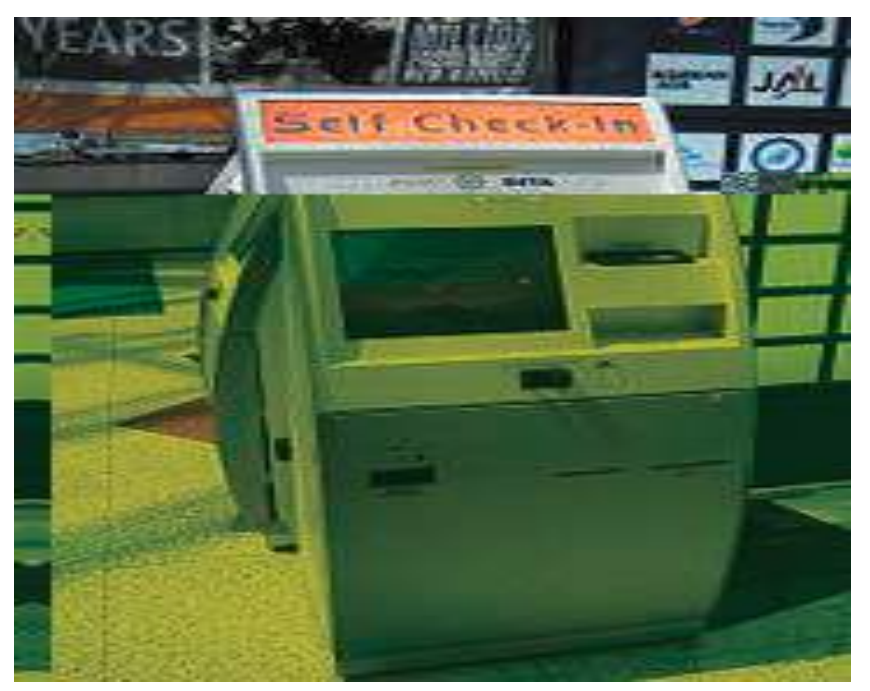

Figure (2): CUSS Kiosk Machine

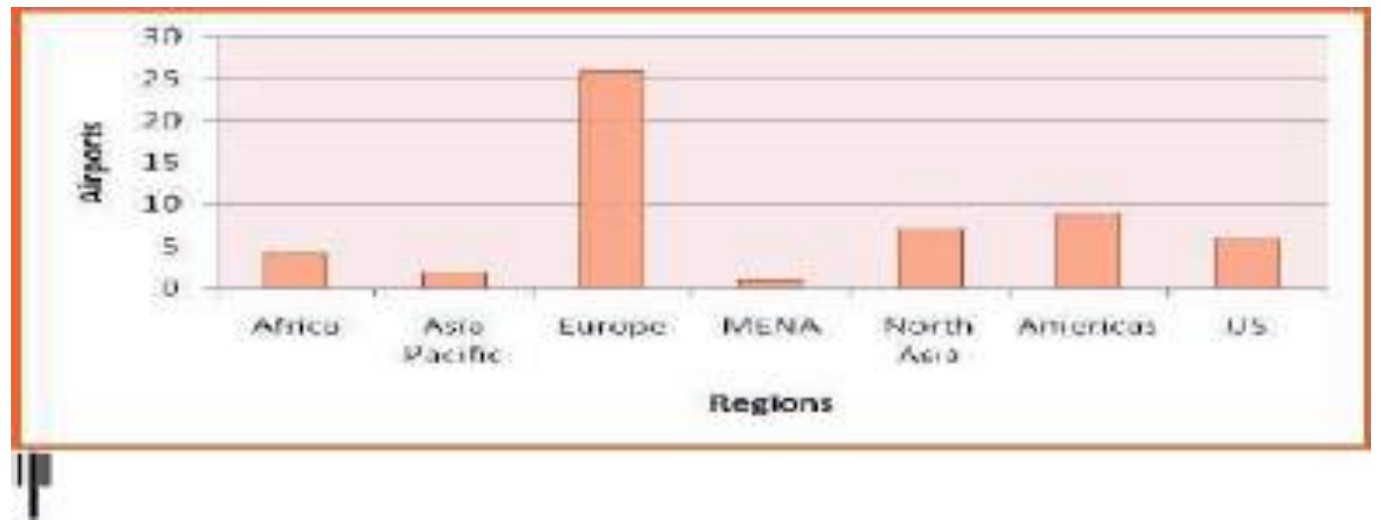

Figure (3): Penetration of CUSS at airports, Source: 18

\section{Methodology}

The study seeks to investigate passengers' intention toward using SST for airline check-in kiosks, and explore the obstacles to use self-service check-in kiosks at Cairo International Airport. A qualitative method has been adopted using in-depth interviews with open-ended questions, since in certain studies it is necessary to acquire the opinion of experts, particularly in qualitative and exploratory studies. Therefore, the researcher has interviewed a sample of 20 Executive directors of Cairo International Airport, check-in counter agents, managers of Egypt Air, and 30 passengers at Cairo International Airport. The interviews have included questions investigating the worth and benefits of using self-service check-in kiosks to airlines, airports and passengers, the limitations of self-service check-in technology for passengers, and the main reasons for the negative attitudes of passengers toward self-service check-in technology. These interviews also aimed at finding out what makes passengers resistant to use self-service check-in technology, and how airlines can encourage passengers to use the CUSS kiosks. The interview forms consist of three sections; the first section is designed generally to investigate the benefits of adopting self-service check-in technology to airlines, airports and passengers. The second section is developed to identify the main reasons for the negative attitudes of passengers toward self-service check-in technology and investigate obstacles of CUSS kiosk system perceived by passengers. The third section is developed to explore the role of airline companies to encourage passengers to use CUSS kiosks. 


\section{Findings}

It was observed that Cairo International Airport (TB3) has installed 10 CUSS kiosks; and despite long queues for various flights at the counter, none were using the kiosks. Passengers had rejected the kiosks and had some obstacles to use kiosks. They prefer to wait in the long queue following the traditional check-in methods instead of using self-service check-in machines. So, The in-depth interviews reveal a wealth of information on the passengers' intention to use technology-based self check-in services at Cairo International Airport from the passengers' and the airline managers' point of view in the following three section.

The first section: The benefits of adopting self-service check-in kiosks for airlines, airports, and passengers.

(1) As for airline managers and check-in counter agents, the majority of respondents (78\%) have demonstrated that the importance of the kiosk to the airlines is high. Obviously, it does not only reduce the manpower cost, minimize expenditures and increase the income of the company, but also assists in the promotion of the airlines' image by providing another checkin service option, an advanced one, to passengers. It also mitigates pressure at the check-in counters and reduces check-in processing time.

Relevantly, other respondents ( 9 employees) added that self-service check-in kiosks deliver fast and smooth services to airline passengers, and improve operational efficiency. Self-service check-in kiosks put control into the hands of the customer. In the airline industry, this control comes in the form of enabling the customer to select their own seat, request an upgrade, or change flights.

Moreover, many executive directors of Cairo International Airport ( 8 respondents) clarified that self check-in procedures appear more important and effective for business travelers who often carry one luggage only more than for other passengers.

(2) Regarding passengers: A number of passengers (67\%) have assured that self-service check-in kiosks act as a time saver for passengers as they allow passengers to cut down on time wasted standing in line. Furthermore, they provide customers with various benefits, such as flexibility in use, avoiding service personnel, increasing control over the service delivery, and convenience. They also act as a space saver for airports.

The second section: The main reasons for the negative attitudes of passengers toward self-service check-in kiosks, and obstacles to using CUSS Kiosk perceived by passengers.

(1) The results indicate that high percentage of passengers (82\%) argue that there are several impediments which prevent them to use such machines: Firstly, they hesitate to use self check-in machines for fear of making mistake, due to its complex interface; they do not know how to use it and they are afraid to take any risk by doing wrong interaction with selfservice check-in machines. Therefore, passengers still prefer interaction with front-line employees.

Furthermore, some respondents (4 passengers) also claimed that such kiosks have not been advertised or promoted, this most certainly precludes use; they have never seen that kind of machine and cannot recognize it. Furthermore, these kiosks are not visible due to its location at the airport.

Other respondents (5 passengers) added that passengers with luggage had to queue again for luggage services at the checkin counters for delivering the baggage. So, this process leads to waste of time as they do not get the bag-tag through self check-in kiosks.

Secondly, many respondents (17 passengers) pointed to issues concerning the obstacles related to CUSS Kiosk system. They stated that they have avoided using it due to Kiosk service failure and system breakdown, and the new procedures are not trusted completely for them.

(2) From the leaders/mangers at Cairo International Airport and check-in counter agents' viewpoint: The majority of respondents (84\%) pointed out that passengers are not commonly using Self-service check-in kiosks and had rejected it due to some obstacles, such as the lack of passengers' assistance to complete the process through the self-service check-in kiosks, and the airline staff's lack of training. Moreover, personal characteristic, beliefs, and attitudes of the passengers as well as cultural differences and level of education are also quite important factors that affect technology adoption.

Also, other station directors of Egypt air at Cairo International Airport have mentioned that a primary concern acting as impediments to the promotion of the kiosk service is the passengers' sense of insecurity and uncertainty when facing this innovative type of self check-in service. Moreover, passengers would worry about the consequences of using the kiosks. Simply, passengers are unwilling to shoulder the risk of possible inaccuracies when using the kiosks. In addition, they are not sure about the service quality of the kiosk, such as accuracy, and compatibility. Furthermore, if the passengers were not 
able to have self-efficacy in controlling the kiosks' operation processes, they would not tend to use them. Finally, passengers' inclinations for personal interaction might restrain the adoption of the kiosks.

The third section: The role of airline companies to encourage and promote passengers' use of CUSS kiosks.

(1) The majority of passengers ( $75 \%$ ) have agreed that they should be personally guided to use the kiosk by the employees; and airlines should try to change the passengers' attitude toward the kiosks in the future through extensive promotion. Suggested promotional strategies may include vigorous assistance by frontline employees, enhancement of the kiosks' stability, efficiency, accuracy and simplicity of use, and reduction of the adoption risk perception. Moreover, airlines have to establish marketing strategies to encourage passengers to use the cost-effective check-in services.

(2) A high percentage of airline managers and check-in counter agents (86\%) have ensured that it is very important to encourage passengers to use CUSS kiosks through different methods; airlines can give passengers some rewards such as special offers or promotion (e.g. free miles or ticket price discounts for their next flight).

Other executive directors of Cairo International Airport have suggested that airlines and airports' authorities should understand the factors affecting passengers' attitudes and realize the passengers' demands for this new check-in service before being introduced or extensively used. Airlines have to focus on educating customers on how to use check-in kiosks, for example, by organizing campaigns where employees show customers how to use the kiosks.

\section{Conclusion}

Airlines are eager to streamline their organization and apply new information technology to face the challenges of a competitive global market. However, the implementation of new technology is time consuming and requires human resources and enormous capital investment. Furthermore, the implementation of new technology involves innovation in organizational operation and even changes in its competitive mode. Although the widespread application of airport selfcheck-in services has benefited passengers, airlines and airports, passengers do not possess entirely positive attitudes toward it. However, the new procedures (self-service check-in kiosk) are not trusted completely. So, operated check-in procedures are still needed. Thus, exploring the potential obstacles to applying kiosks at check-in services is an issue of critical concern to the aviation industry. Also, low kiosk use and negative response to self-service check-in kiosks are directly related to systemic issues which impede kiosk use. Kiosk-service failures are clearly related to the lack of consistent service personnel to inform and assist passengers to use this service. Therefore, airlines should encourage those passengers who have not yet used kiosks to increase the overall kiosk usage. Finally, airlines should study and review the impact SST has on airlines and customers prior to selecting specific technologies to put in use, and they should also train their employees to know how to use the SST which then results in improved customer use.

\section{References}

(1)Lin, J.C. and Hsieh, P .(2011), Assessing the Self-service Technology Encounters: Development and Validation of SSTQUAL Scale. Journal of Retailing ,87 (2), 194-206.

(2)Oyedele, A. and Simpson, P(2007). An empirical investigation of consumer control factors on intention to use selected self-service technologies. International Journal of Service Industry Management ,18(3), 287-306.

(3)Jasmand, C.(2006) The Adoption of Self- Service Technologies : The Role of Consumer Readiness, Trust, and Experiences , Master Thesis, University of Maastricht. Available at: http://www.grin.com/en/e-book/75028/theadoption-of-self-service, Access on 07/12/2012.

(4)Frary, M. (2005) Self-service future or fad? Amadeus, available at : http:// www.amadeus.com/benelux/documents/corporations/Self-service_white · ...PDF[ access on 23/05/2012]

(5)Oh, H. ; Jeong, M. and Baloglu, S. (2011) Tourists' adoption of self-service technologies at resort hotels, Journal of Business Research, Article in press .

(6)Cunningham, L ; Young, C. and Gerlach , J ( 2008). Consumer Views of Self- Service Technologies .The Service Industries Journal, 28(6), 719- 732.

(7)Lee, J. and Allaway, A. (2002) Effects of personal control on adoption of self-service technology innovations . Journal of Services Marketing, 16(6), 553 - 572.

(8)Lin,J.C. and Hsieh,P. (2007) The influence of technology readiness on satisfaction and behavioral intentions toward selfservice technologies . Computers in Human Behavior, 23 , 1597-1615. 
(9)Liu, S.(2012)The impact of forced use on customer adoption of self-service technologies. Computers in Human Behavior, 28 , 1194-1201.

(10)Curran, J. ; Meuter , M. and Surprenant, C.(2003) Intentions to Use Self-Service Technologies: A Confluence of Multiple Attitudes. Journal of Service Research, 5(3), 209-224.

(11)Alcock, T. and Millard, N. (2007) Self-service — but is it good to talk? BT Technology Journal, 25 (3 \& 4 ) July/October , 313-320.

(12)Hsieh, C.(2005) Implementing Self-Service Technology To Gain Competitive Advantages, Communications of the IIMA , 5 (1), 77- 83 . Available at:http/www.iima.org/CIIMA/CIIMA\%205.1\%2077\%20Hsieh-9.pdf[accessed on 18 March 2012].

(13)Deng, L. (2012) Discrete Emotions and Trust in Self-Service Technology, Proceedings of the Southern Association for Information Systems Conference, Atlanta, GA, USA March 23rd-24th, 2012.

(14)Cho, H. and Fiorito, S.(2010) . Self-Service Technology in Retailing. The Case of Retail Kiosks, Symphonya . Emerging Issues in Management, n. 1, pp. 42-54. Available at: http// webdepot.gsi.unimib.it/symphonya/RePec/pdf/symjournl05.pdf[accessed on 02April 2012].

(15)Liljander,V.; Gillberg,F.; Gummerus, J.and van Riel,A. (2006) Technology readiness and the evaluation and adoption of self-service technologies. Journal of Retailing and Consumer Services, 13, 177-191.

(16)Wang, C.; Harris, J. and Patterson, P. (2009) Situational Influences in the Choice of Self-Service in a Multi-Channel Retail Context , ANZMAC, Available at: http://www.duplication.net.au/ANZMAC/09papers/ANZMAC2009.261-pdf , [Access on 20 May 2012].

(17)Wang, C.; Harris, J. and Patterson, P.(2012) Customer choice of self-service technology: the roles of situational influences and past experience. Journal of Service Management, 23 (1), 54 - 78.

(18) Baxi, M. (2007) Developing A Model To Analyze Impacts Of Self- Service And Web Check-In at Airports , the degree of Master of Science in Airport Planning and Management, Cranfield University.

(19)Chang, H.L. and Yang ,C.H. (2008) Do airline self-service check-in kiosks meet the needs of passengers?. Tourism Management, $29,980-993$.

(20)Howes, J. (2006) Moving to Common Use Self-Service (CUSS), available at : http:// www. iata. org/whatwedo/stb/Documents/On\%20the\%20cusp\%20of\%20CU [ access on 24/10/2012].

(21)Wittmer, A.(2011) Acceptance of self-service check-in at Zurich airport. Research in Transportation Business \& Management, 1 (1), 136-143.

(22)Kusumasondjaja, S.(2009) . Consumer Characteristics and Responses to Failures of Self-Service Technology, Available at: http// www.duplication.net.au/ANZMAC09/papers/ANZMAC2009-248.pdf[accessed on 02April 2012].

(23)Srijumpa , R. and Speece, M. (2004) Understanding Technology-Based Self-Service Encounters: Asian Services In The New Era, Asia Academy OF Management Fourth Conference "Moving Forward: Leading Asia in a New Era" Shanghai, China December 16-18, 2004.

(24)Grenci, R. and Watts, C.( 2007) Maximizing customer value via mass customized e-consumer services, Business Horizons , 50, 123-132.

(25)Abdel Aziz,S .; Hegazy, A. and Elabbassy, A. (2010). Study of Airport Self-service Technology within Experimental Research of Check-in Techniques Case Study and Concept. International Journal of Computer Science Issues, 7 (3) No 1, 17-26.

(26)Nysveen, H. and Pedersen, P. (2011) . Best practices and empirical analysis for the improvement of customer experience, SNF Working Paper No 05/11.

(27)Bitner, M. (2007) Self-Service Technologies: Innovation and Execution, IEEE/INFORMS NSF Workshop on Service Science, Available at: http//www.personal.psu.edu/gxq102/Research/NSFWorkshop2007/2007NSF/NSF...28/03/2012 06.00 pm[accessed on 28 March 2012]. 
(28)Bitner, M.; Ostrom , A. and Meuter, M. (2002) Implementing Successful Self-Service Technologies. The Academy of Management Executive, 16(4), 96-108.

(29)Castro,D. ; Atkinson, R and Ezell, S(2010) Embracing the Self-Service Economy, The Information Technology \& Innovation Foundation, Available at: http// www.itif.org/publications/embracing-self-service-economy [accessed on 28 March 2012].

(30)Neo, K C. (2010) Embracing self-service technology for hotel productivity growth, University of Nevada, Las Vegas UNLV Theses, Master of Hospitality Administration http://www.digitalcommons.library.unlv.edu/hgs_Profpapers/index.2.html.

(31)Phongkusolchit ,K.( 2008) Improving Self-Service Technologies Utilization: The Potential Impacts OF Technology Anxiety, Need For Interaction With Service Employees, And Expected Service Quality, Southern Illinois University Carbondale, Department of Management, Doctor of Philosophy Degree.

(32)Kelly,P.; Lawlor, J and Mulvey,M(2010). A Review of Key Factors Affecting Consumer's Adoption And Usage of Self- Service Technologies In Tourism, Available at: http//www.shannoncollege.com/wpcontent/uploads/2009/12/THRIC-2010-Full... /... [accessed on 13 March 2012].

(33)Kasavana, M .(2010). Emergent Service Delivery Technologies. The Journal of International Management Studies, $5(2), 159-167$.

(34)Meuter, M.; Ostrom, A.; Roundtree, R. and Bitner, M.(2000). Self-Service Technologies:

Understanding Customer Satisfaction with Technology-Based Service Encounters, Journal of Marketing , 64, 50-64.

(35)Yang, M. and Park,K.H.(2010) Self-Service Technologies (SSTs): determinants of adoption and its post-usage outcomes from a focal company perspective, Int. J. Services and Operations Management, Available at: http://www.markyang76.files.wordpress.com/2010/10/ijsom-8303-yang-and-park.pdf ,[accessed on 23 May 2012]

(36)Preda, O. ;Ivănescu, I. and Furdui, I. ( 2009) Self- Service Technologies Speak For Themselves, Romanian Economic and Business Review , Romanian-American University, 4 (1), 11- 17.

(37)Bashir ,M. and Albarbarawi,S.( 2011) Factors Influencing the Adoption of Self Service Technologies (SSTs) : A study of attitudes towards SSTs (Internet Banking, Online Shopping and Self-Check-In Machine at the Airports) and the influence of new technologies (smart phones and tablet computers), Master 's Thesis, Umeå Universitet, Institutionen för Informatik, Available at: http:// www.essays.se/about/Technology-Based+Self-Service,[accessed on 19November 2012]

(38)Curran, J. and Meuter, M. (2005).Self-service technology adoption: comparing three technologies. Journal of Services Marketing, 19 (2), 103-113.

(39)Kim, J. ; Christodoulidou, N. and Brewer, P. ( 2012) Impact of Individual Differences and Consumers' Readiness on Likelihood of Using Self-Service Technologies at Hospitality Settings, Journal of Hospitality \& Tourism Research, 36( 1), 85-114.

(40)Walker, R and Johnson, L (2006) Why consumers use and do not use technology-enabled services. Journal of Services Marketing, 20(2) , 125-135.

(41)Habibi, S.(2008) Intention to Adopt Technology -Based Self- Services, The case of Airport Self Check- in Service for Iran Aviation Industry, Master 's Thesis, Lulea University of Technology, Available at: http://www epubl.ltu.se/16530187/053/2008/LTU-PB-EX-08053-SE.pdf · PDF, ,[accessed on 02 April 2012] .

(42)Wang, J. and Namen, J. (2004) Customer Adoption of Technology -Based Self- Services, A Case Study on Airport Self Check- in Service, Master 's Thesis, Lulea University of Technology

Available at: http://www._epubl.ltu.se/1404-5508/2004/085/LTU-SHU-EX-04085-SE.pdf · PDF ,[accessed on 30April 2012]

(43)Dabholkar, P. (1996) Consumer evaluations of new technology -based self service options: An investigation of alternative models of service quality, International Journal of Research in Marketing, 13(1), 29-51.

(44)Hilton, T. and Hughes, T. (2008). Co-production and co-creation using self service technology: The application of service-dominant logic, Otago Forum 2, Academic Papers, Paper no: 4, pp.22-40, Available at: http//marketing.otago.ac.nz/events/OtagoForum/Final\%20forum\%20papers/... [accessed on 18 March 2012]. 
(45)Walker, R. ; Lees, M.C.; Hecker, R. and Francis, H. (2002) "Technology-enabled service delivery: An investigation of reasons affecting customer adoption and rejection". International Journal of Service Industry Management, Vol. 13( 1) , 91 - 106.

(46)Fui , C.K.(2008) Self-Service Technology And Internet Banking: An Investigation Of Consumers’ Trial Decision , Faculty Of Business And Accountancy, University Of Malaya, Master of Business Administration.

(47)Simon, F. and Usunier, J.C. (2007). Cognitive, demographic, and situational determinants of service customer preference for personnel-in-contact over self-service technology. International Journal of Research in Marketing , 24 , 163-173.

(48)Natarajan,T. (2010) Customer's Choice amongst Self Service Technology (SST) Channels in Retail Banking: A Study Using Analytical Hierarchy Process (AHP). Journal of Internet Banking and Commerce, 15(2) .

(49)Featherman, M. and Pavlou, P.( 2002) Predicting E-Services Adoption : A Perceived Risk Facets Perspective, Eighth Americas Conference on Information Systems, 1035-1046 .

(50)Lema, J. (2009) Preparing Hospitality Organizations for Self-Service Technology. Journal of Human Resources in Hospitality \& Tourism,8(2), 153-169.

(51)Zhu , Z. ; Nakata, C ; Sivakumar,K. and Grewal,D.( 2007), Self-service technology effectiveness: the role of design features and individual trait. Journal of the Academy of Marketing Science, 35,492-506.

(52)Zhu, Z. (2002) Fix it or leave it: Antecedents and consequences of perceived control in technology-based self-service failure encounters, the degree of Doctor of Philosophy in Business Administration ,University of Illinois , Chicago .

(53)Oh, H. and Jeong, M.(2009). A Self-Service Technology Adoption Model in the Resort Hotel Environment, Hospitality $\&$ Tourism Management International CHRIE Conference-Refereed

Track ,Available at: http// content.sp.npu.edu.tw/teacher/benson/Shared\%20Documents... [accessed on 14 March 2012].

(54)Bitner, M., Brown, S. and Meuter, M.(2000) Technology Infusion in Service Encounters. Journal of the Academy of Marketing Science, 28(1),138-149.

(55)Hsun Ho,S. and Yin Ko,Y. (2008) Effects of self-service technology on customer value and customer readiness: The case of Internet banking. Internet Research, 18(4), 427 - 446.

(56)Rose, J. and Fogarty, G.(2006). Determinants Of Perceived Usefulness And Perceived Ease Of Use In The Technology Acceptance Model: Senior Consumers' Adoption Of Self-Service Banking Technologies, Academy of World Business, Marketing \& Management Development Conference Proceedings, 2 (10), 122-129.

(57)Travica, B . (2008) Influence of Information Culture on Adoption of a Self-Service System, Journal of Information, Information Technology, and Organizations , Volume 3. Available at: http://www.questia.com/library/p409628/journal-of-information-information-technology,[accessed on 2012] .

(58)Dabholkar, P. and Bagozzi, R.P. (2002). An attitudinal model of technology-based self-service:moderating effects of consumer traits and situational factors. Journal of the Academy of Marketing Science, 30(3), 184-201.

(59)Fitzsimmons, J. (2003) Is self-service the future of services?. Managing Service Quality, 13

(6), $443-444$.

(60)Davis, D. ; Bagozzi, R.P. and Warshaw, P.R. (1989) User Acceptance of Computer Technology: A Comparison of Two Theoretical Models, Management Science 35 (8), 982-1003.

(61)Collier, J.E.(2006) Examining customers' intentions to use self-service technology through utilitarian and hedonic value judgments, the degree of Doctor of Philosophy in Business Administration ,University of Memphis, Chicago .

(62)Cho , S.(2011) Self-Service Technology : AN Investigation OF The Potential For Adoption In Apparel Retail Settings, the degree of Doctor of Philosophy ,University of North Carolina at Greensboro.

(63)Lee, H.J.; Cho, H.J.; Xu ,W. and Fairhurst , A.(2010). The influence of consumer traits and demographics on intention to use retail self-service checkouts . Marketing Intelligence Planning , 28 (1), 46-58.

(64)Dabholkar, P., Bobbitt, L. and Lee, E.(2003) Understanding Consumer Motivation and Behavior Related to SelfScanning in Retailing: Implications for strategy and research on technology-based self-service. International Journal of Service Industry Management, 14(1), 59-95. 
(65)Dean, D.(2008) Shopper Age and the Use of Self-Service Technologies, Managing Service Quality, 18(3), 225-238.

(66)Meuter, M.; Bitner, M.; Ostrom, A. and Brown, S.(2005) Choosing Among Alternative Service

Delivery Modes: An Investigation of Customer Trial of Self-Service Technologies . Journal of Marketing, 69 , 61-83.

(67)Weijters, B. ; Schillewaert, N. ; Rangarajan, D. and Faik, T. (2005) Customers' usage of Self Service Technology in a Retail Setting, Vlerick Leuven Gent Management School ,Working paper series ,available at : http:// www ideas.repec.org/p/vlg/vlgwps/2005-19.html[access on 28/03/2012].

(68)Parasuraman, A .(2000). Technology readiness index (tri): a multiple-Item scale to measure readiness to embrace new technologies. Journal of Service Research 2 (4), 307-320.

(69)Meuter, M.; Ostrom, A.; Bitner, M. and Roundtree, R.(2003) The influence of technology anxiety on consumer use and experiences with self-service technologies. Journal of Business Research, 56 (11) , 899- 906 .

(70)Mick, D. G., \& Fournier, S. (1998). Paradoxes of technology: consumer cognizance, emotions, and coping strategies. Journal of Consumer Research, 25(2), 123-144.

(71)Chen,S.C. and Han Li,S.(2010) Consumer adoption of e-service: Integrating technology readiness with the theory of planned behavior, African Journal of Business Management, 4(16), 3556-3563.

(72)Lin,J.C. and Hsieh, P.(2006).The role of technology readiness in customers' perception and adoption of self-service technologies . International Journal of Service Industry Management, 17(5), 497-517.

(73)Stockdale ,R.(2007). Managing customer relationships in the self-service environment of e-tourism . Journal of Vacation Marketing, 13( 3), 205-219.

(74)Gelderman,C.J.; Ghijsen,P.W.Th ; Diemen,R.V.(2011) Choosing self-service technologies or

interpersonal services- The impact of situational factors and technology- related attitudes,

Journal of Retailing and Consumer Services, Volume 18 , Issue 5 , PP. 414- 421.

(75)Lu, J.L. ; Choi,J.K. and Tseng,W.C.(2011) Determinants of passengers' choice of airline check-in services: A case study of American, Australian, Korean, and Taiwanese passengers .

Journal of Air Transport Management, 17 (4), 249-252.

(76)Robertson, N. and Shaw, R.(2008) Exploring self-service technology powerlessness, in ANZMAC 2008 :

Australian and New Zealand Marketing Academy Conference 2008 : Marketing : shifting the focus from mainstream to offbeat, Promaco Conventions, Canning Bridge, W.A., pp. 1-7.

(77)Dickinson, C. (2006). Self-service Technologies: The Affect on Hospitality Branding, available at:http//www.hospitalityupgrade.com/_magazine/magazine_Detail-ID-42.asp[accessed on30April 2012].

(78)Kasavana, M. and Connolly, D.(2005) . Self- Service Kiosks : Hotels Expand Guest Services. The journal of Hospitality Financial And Technology professionals . Special Issue Self- Service Technology , 20( 2), 11-14 .

(79)Lin,J.C. and Chang, H.C.(2011) .The role of technology readiness in self-service technology acceptance . Managing Service Quality, 21(4) , 424-444.

(80)Coker,F. (2009) Consumer Attitudes And Behavioral Intention Towards Self-Service Kiosks In Hotels : A Cultural Perspective, the degree of Master of Science in Hospitality Information Management, University of Delaware.

(81)Fisher, G \& Beatson, A.T. (2002) The impact of culture on self-service on technology adoption in the hotel industry. International Journal of Hospitality and Tourism Administration, 3(3), 59-77.

(82)Black, C.(2009) Self-Service technologies: Chinese Passenger Responses to Airport Check-In, Master 's Thesis, National Cheng Kung University, Institute of International Business .

(83)Lu, J.L. ; Chou,H.Y and Ling,P. C. (2009) Investigating passengers' intentions to use technology-based self check-in services . Transportation Research Part E: Logistics and Transportation Review, 45 Issue (2) , 345-356. (84)Drennen, H. (2011) Self Service Technology in Airports And the Customer Experience, UNLV Theses, Master of Hospitality Administration, available at : http:// www.digitalscholarship.unlv.edu/thesesdissertations/1053[ access on 22/01/2013]. 
(85)Abdullah, N.Ab.H.(2012) Technology Readiness and Users Satisfaction towards Self-Service Technology at Malaysian Airport . Information Management and Business Review , 4( 8), 453-460.

(86)Moerloose, C. ; Antioco, M.; Lindgreen, A. and Palmer, R.(2005) Information kiosks: the case of the Belgian retail sector. International Journal of Retail \& Distribution Management, 33( 6) , 472-490.

(87)IATA (2011) The International Air Transport Association ,available at : http://www. internationalairtransportassociation. com [ access on 24/10/2012].

(88)wikipedia (2011) Common Use Self Service available at: http://www. en.wikipedia.org/wiki/ Common_Use_Self_Service[ access on 24/10/2012].

(89)Airport Business (2012) The evolution of the kiosk ,available at : http://www.airport-business.com/2012/06/theevolution-of-the-kiosk [ access on 24/10/2012].

(90)Kidwell, H. (2007) Going it Alone: Self-Service Check-In Kiosks, Airport Technology, available at: http:// www. airport-technology. com/features/feature1179 [ access on 24/10/2012].

(91)Annapolis , M. (2009) ARINC Supports the Opening of Cairo Terminal 3 with 14 Advanced Airport Systems Installed and Running, available at: http:// www.arinc.com/news/2009/08-17-09-arinc-supports-opening-of-Cairo-terminal3.html[ access on 24/10/2012].

(92)Cairo International Airport (2012) available at: http:// www.airport-technology.com//projects/cairointernational [ access on 24/10/2012].

(93)Ministry of civil Aviation (2012) Egyptian Holding Company for Airports and Air Navigation, available at: http:// www:ec.europa.eu/.../modes/air/events/doc/eu_africa/session_6_cairo.pdf .

(94)Gualandi,N.; Mantecchini, L. ; Paganelli,F. ( 2011) The Impact Of New Technologies In Airport Passengers' Processes, available at : http:// wwwgeocities.ws/icts_papers/Papers/Gualandi,\%20Montecchini,\%20 ...PDF [ access on $22 / 01 / 2013]$.

\section{معوقات تطبيق تكنولوجيا الخدمة الذاتية في مطار القاهرة الدولي}

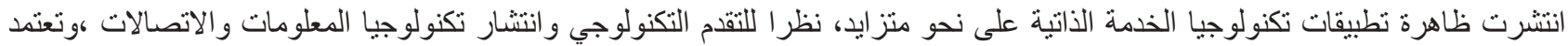

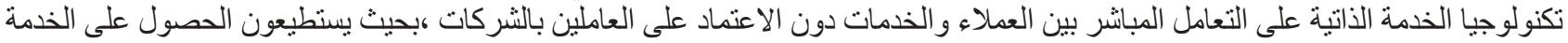

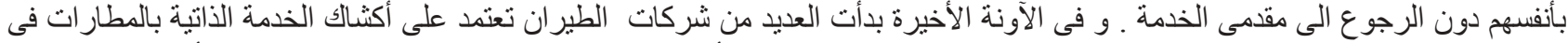

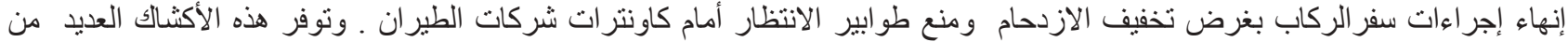

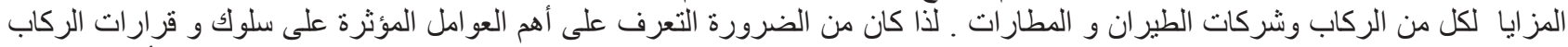

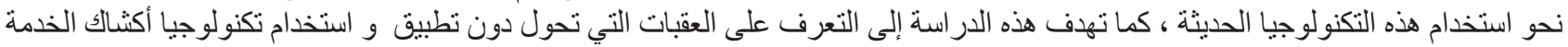

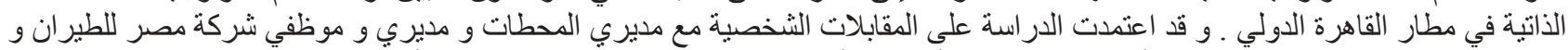

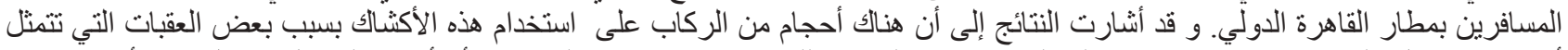

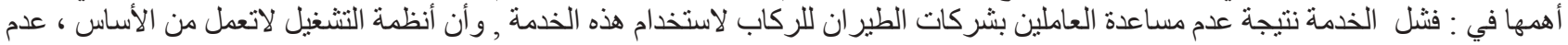

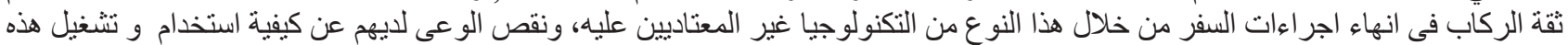

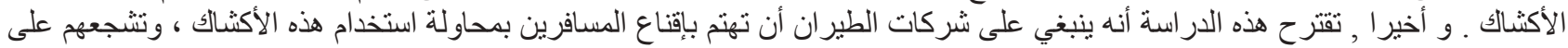

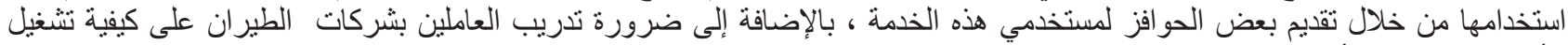
الأكثاك مما ينعكس أثره بالتالي على تحسين و تعظيم استخدام العملاء للخدمة . لإضي 